\title{
Carbon cycling from source to sink in magmatic orogens
}

\section{CIN-TY LEE}

Rice University

Presenting Author: ctlee@rice.edu

On geologic timescales, magmatism is considered the primary source of $\mathrm{CO} 2$ into the exogenic system while and organic carbon burial and silicate weathering followed by carbonate deposition represent the long-term sinks of carbon. In general, these magmatic sources of $\mathrm{CO} 2$ do not directly influence the nature carbon sequestration other than through enhancing $\mathrm{pCO} 2$, which in turn enhances the efficiency of chemical weathering. However, magmatic orogens are far more complex in terms of $\mathrm{C}$ cycling. On the one hand, continental volcanic arcs, such as the modern Andes or Cretaceous North American Cordilleran arc, output large amounts of $\mathrm{CO} 2$ due to contributions from the subducting slab and ancient carbonate-rich metasediments in the continental crust. Because the carbon content in the bulk continental crust has likely increased with time, the $\mathrm{CO} 2$ outputs from continental arc volcanoes may have increased with time. Physical weathering efficiency, however, is enhanced in magmatic orogens owing to tectono-magmatic uplift and high relief. This, in turn, could increase the efficiency of silicate weathering and removal of $\mathrm{CO} 2$ by carbonate precipitation. Magmatic orogens are also often associated with the formation of shallow back-arc basins, which because of their restricted nature, favor the preservation of organic C. Volcanic ash from these magmatic orogens may also serve as a nutrient, enhancing biological productivity. Collectively, these processes may increase the efficiency of carbon sequestration via carbonate and organic $\mathrm{C}$ deposition. A key question arises. In magmatic orogens, are volcanic inputs of carbon and the efficiency of outputs in phase? Answering this question requires an understanding of how magmatism influences rates of uplift and erosion as well as the nature of continental back-arc basin formation. In short, there is a complex interplay between tectonics, magmatism, erosion, and basin formation that warrants further study. I show that after magmatism ends, the conditions for enhanced weathering and organic carbon burial persist. If so, this would imply that global flare-ups in arc activity, particularly continental arcs, should lead to greenhouse conditions, but icehouse conditions are predicted in the aftermath. 